\section{JOHN CROSTHWAITE BRIDGE}

By the death of Dr. J. C. Bridge on September 27, Industrial Health has lost one of its outstanding figures who contributed much to the development of this service. Born in 1877, the second son of the Reverend James Henry Bridge, he was educated at Carlisle Grammar School and the Middlesex Hospital, gaining an entrance exhibition. Qualifying with the English Conjoint Diploma in 1902, his subsequent academic achievements were successively the D.P.H. of Cambridge in 1906, the F.R.C.S.(Ed.), in 1910, Barrister-at-Law (Middle Temple) in 1913, and the M.R.C.P.(Ed.) in 1920.

After serving first with the Carnegie Institute, Dunfermline, then as Assistant Medical Officer of Health, Devonport, and then as Medical Officer of Health for Breconshire, he entered the Home Office in 1914 as H. M. Medical Inspector of Factories. Here he was to find his life's work, serving for 29 years in the Factory Department, the last sixteen years as Senior Medical Inspector in succession to Sir Thomas Legge. During the 44 years of service of these two men, this country led the world in the application of medical science and practice to the development of industrial health legislation, and they were successively the dominant figures in this work.

Bridge was eminently practical, skilled in codifying knowledge and experience. He was particular in his pursuit of truth, and insistent on accuracy in himself and others. He was a clear thinker and fast worker, and eagerly sought for new knowledge to apply to specific problems in industrial health and so to increase the efficiency of preventive measures. Bridge really knew industrial processes and the comparative hazards attached to different stages of them. Thus it was that his contribution to the progress of industrial health was cumulative and widespread. He held strongly that legislation concerned with prevention should go hand in hand with legislation relating to compensation, and here too, as Adviser to the Home Officer on medical aspects of the law relating to compensation, he left his mark. He was assiduous in identifying new occupational diseases and ensuring their consideration with a view to their inclusion in the schedule of diseases subject to compensation.

He was a member of the Departmental Committee of 1930 on extensions to the Schedule of Industrial Diseases, and of another Committee in 1935 on certain questions arising under the Workmen's Compensation Act. He was Chairman of the Departmental Committee on Medical Arrangements for the Diagnosis of Silicosis in 1928, a member of the Industrial Health Research Board, of the Industrial Pulmonary Diseases Committee, and of the Committee on Industrial Solvents of the Medical Research Council, and of many other Committees such as the Ministry of Health's Committees on the Causes and Prevention of Blindness (1922), on Cancer (1928-35), on Ethyl Petrol (1928), and the Advisory Departmental Committee on Anthrax (1935-46), and the Correspondence Committee on Industrial Hygiene of the Inter-

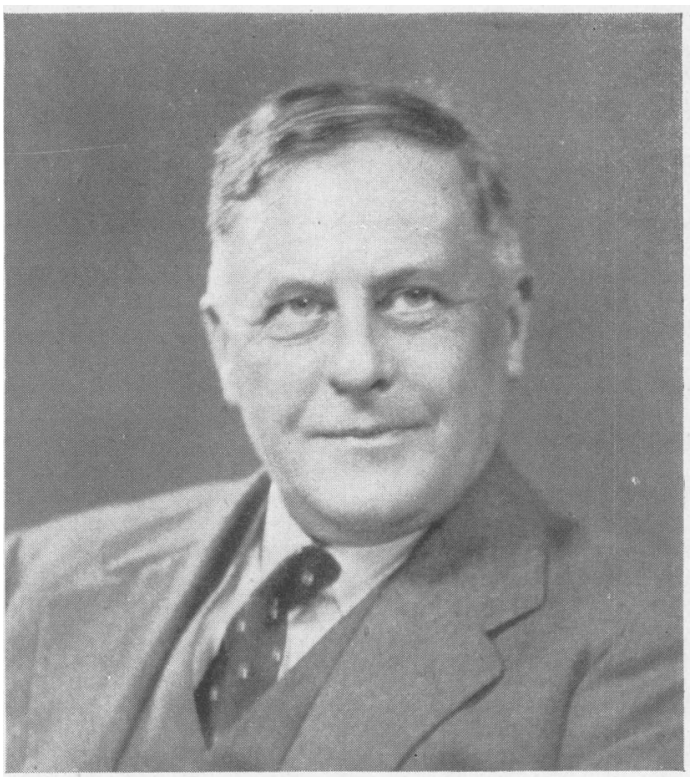

national Labour Office from 1927. He was vice-president of the Section of Occupational Diseases at the Annual Meetıng of the British Medical Association in Manchester in 1929 and of the Section of Public Health at the Centenary Meeting in 1932. A very early member of the Institution of Professional Civil Servants, he became a member of Council and twice held the office of Chairman from 1922-26 and again from 1930-31. After his retirement from the Factory Department, he became Chairman of the Association of Industrial Medical Officers and also Consulting Officer to Imperial Chemical Industries.

Although so active in public affairs, Bridge was inherently retiring and sensitive, but he had withal a most disarming and appealing charm of word and manner. His colleagues, especially the junior ones, knew that he kept of his best for them. He was never too busy to discuss knotty points, and they never forgot how doubts and difficulties would vanish under his skilled analysis. Those who sat at his feet have an abiding gratitude for his unobtrusive teaching and his touch of genius - the full force of which was apparent only in retrospect. And so throughout his service he commanded a happy crew in a happy ship, whatever the hazards of the voyage.

Dr. Bridge was made a C.B.E. in 1934 and appointed Honorary Physician to H.M. The King in 1937.

He married first in 1904 Bessie (died 1933), daughter of Gateward Coleridge Davis, and in 1935 Joan Phyllis, daughter of James S. Hann, who survives him with one daughter. 